
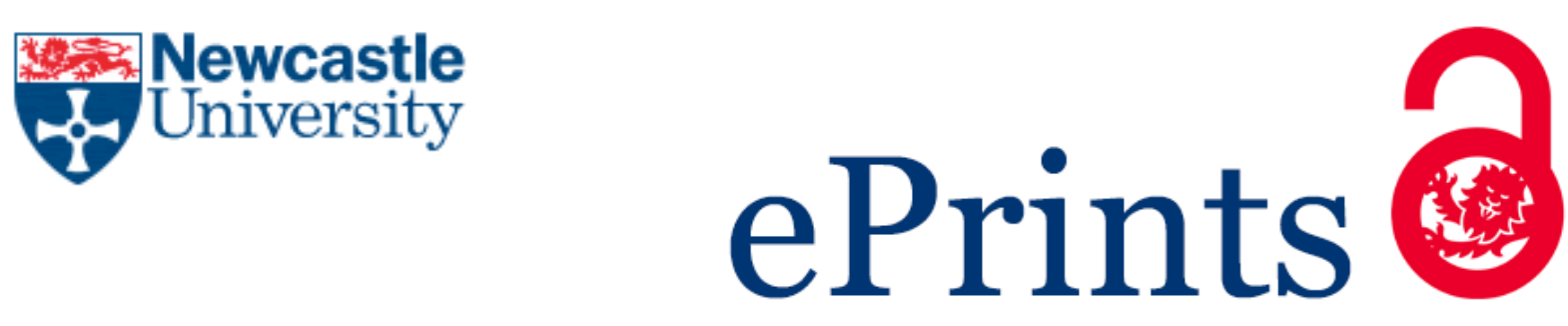

Jones JR.

The student experience of undergraduate students: towards a conceptual

framework.

Journal of Further and Higher Education 2017

\title{
Copyright:
}

This is an Accepted Manuscript of an article published by Taylor \& Francis on 25/7/2017, available online: https://doi.org/10.1080/0309877X.2017.1349882

DOI link to article:

https://doi.org/10.1080/0309877X.2017.1349882

Date deposited:

$20 / 12 / 2017$

Embargo release date:

25 January 2019

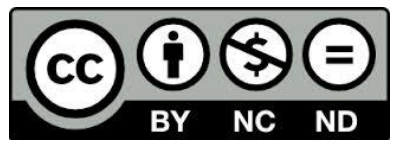

This work is licensed under a

Creative Commons Attribution-NonCommercial-NoDerivatives 4.0 International licence 
Title of the Paper:

The Student Experience of Undergraduate Students: Towards a Conceptual Framework

\section{Personal Details:}

Dr. Rob Jones, Senior Lecturer in Accounting and Finance, Newcastle University.

\section{Address:}

Newcastle University Business School, 5 Barrack Road, Newcastle upon Tyne, NE1 4SE, United Kingdom.

\section{Telephone Number:}

+44(0)1912081602

\section{E-Mail:}

Rob.Jones@ncl.ac.uk 


\title{
The Student Experience of Undergraduate Students: Towards a Conceptual Framework.
}

\begin{abstract}
While the term "student experience" is used widely in universities, it is remarkably underdeveloped as a construct in the academic literature. This paper addresses this gap by proposing a conceptual framework for the student experience of undergraduate students.
\end{abstract}

The approach taken is to identify the key influences that shape the student experience from the perspective of students. It does this by addressing two questions: firstly, what are the key influences that shape the student experience? Secondly, how do these influences shape the student experience? To do this the paper draws from a wide range of studies that provide substantial theoretical and empirical evidence as to how students experience university.

Drawing from Bronfenbrenner's bioecological model of human development, it identifies seven key sets of influences or microsystems that shape the undergraduate student experience. Then the paper considers how these influences shape students' experiences drawing from the concepts of engagement and alienation.

The paper concludes by proposing a broadly defined model for the student experience where learning and development takes place as a result of meaningful interactions between the student and the key microsystems. The implications of this model for universities and for further study are also discussed.

\section{Keywords}

student experience, conceptual framework, undergraduate, students, engagement, alienation.

\section{Word Count}

Text including Abstract: $\quad 6,446$

References:

Total: 


\section{Introduction}

The term "student experience" has become increasingly prevalent in higher education over the past ten years. It appears in a variety of contexts, connected both with policy and practice in several different countries, for example National Survey of Student Engagement (2015), Radloff (2011), Strydom and Mentz (2010), Temple et al. (2014), UES Consortium (2015), Universities UK (2016). However, researchers have been surprising reticent in discussing, debating and articulating the meaning of this term. As Ainley (2008) notes: 'studies have focused almost exclusively on classroom/learning examples, with fewer attempts to understand student life more generally' (p.619).

This paper seeks to address this issue directly, by proposing a conceptual framework for the student experience of undergraduate students; and indirectly, by seeking to draw others into greater debate about the meaning of this widely used but undefined and under-theorised term. To do this the paper addresses two related questions. Firstly, what are the key influences that shape the student experience? Secondly, how do these influences shape the student experience?

The paper adopts the following structure. First, it briefly explores how the term is conceptualised in higher education, noting that it is broadly based, involving learning in a variety of contexts. Discussion of the concept is developed further through reference to a number of influential studies that examine the process of interaction between an individual and their environment. A common theme is identified, that repeated interaction between an individual and their environment is linked to learning; the extent of that learning being determined by the characteristics of the individual, the characteristics of the environment and the degree of interaction that takes place. This forms the basis for the central theme of this paper that the student experience involves a complex series of interactions between a student and the various component parts of their environment which can, depending on the nature of the interaction, result in student learning.

Building from this solid theoretical base, the paper moves on to address the first question, what are the key influences that shape the undergraduate student experience? It does this by identifying the elements of the student's environment that have the greatest capacity to exert influence. Based on a review of the literature the paper identifies seven sets of influences that have the capacity to shape the undergraduate student experience. The studies cited provide substantial theoretical and empirical evidence that the seven groupings are highly significant in defining the environment of undergraduate students.

The paper then addresses the second question: how do these influences shape the student experience? This is done with reference to the established concepts of engagement and alienation. Influences are seen to shape students' experiences when students actively interact with them, thereby contributing to learning and personal development. In contrast where students feel alienated, interaction is limited and passive, restricting the level of learning.

The paper concludes by proposing a model of the undergraduate student experience in which the student experience is determined by the extent of a student's interactions with the key influences that define their environment. The concluding section also discusses some implications of this model for universities and further study.

Thus, the contribution of this paper is to address a gap in the literature by articulating a conceptual framework for the student experience of undergraduates. Drawing from a 
substantial evidence base that represents the views of students themselves, the paper recognises that there are a variety of influences that compete for the attention of an undergraduate student beyond the more structured confines of the classroom.

\section{Student Experience: Practice and Theory}

Analysis of use of the term "student experience" in practice and policy reveals a range of perspectives. In some contexts, greater significance is attached to the student's academic learning experience (Universities UK, 2016) while in others the definition is drawn very widely as the "totality of a student's interaction with the institution" (Temple et al., 2014 p.3). Outside the UK, the term is also used in connection with discussions of student engagement, for example in the USA (National Survey of Student Engagement, 2015), New Zealand (Radloff, 2011), South Africa (Strydom and Mentz, 2010) and Australia (UES Consortium, 2015) leading to the suggestion that institutional efforts to improve the student experience should be directed towards providing opportunities for student engagement (Strydom and Mentz, 2010). This suggests similarities between a broadly-based conception of the student experience that extends beyond academic learning and a conception of student engagement that encompasses more broadly based "educationally purposeful experiences" such as extracurricular activity and interaction with other students (National Survey of Student Engagement, 2015). Discussion of the term "student experience" also suggests an implicit assumption that a good student experience should involve a significant degree of learning and personal development (Temple et al., 2014; Universities UK, 2016).

This creates a challenge in identifying a suitable theoretical framework through which to appraise the student experience. Use of the term student experience in practice suggests that there are multiple influences and multiple locations in which the student experience unfolds. Analysis of such a process requires a theoretical perspective that is sufficiently broad and flexible to accommodate these multiple dimensions. Thus, while we might expect to refer to an established theory of learning, such as surface and deep level learning (Marton and Säljö, 1976), to inform our understanding, the insight provided by such a model is restricted to the context of academic learning, limiting its suitability to appraise the student experience which involves wider aspects of student life.

In such circumstances, it is appropriate to draw from established theories in other fields. Although more closely associated with the field of developmental psychology, Bronfenbrenner's $(1977,1994,1999)$ ecological model provides one such perspective. His model examines the process whereby an individual interacts with his/her environment and has been applied to provide insight in a variety of settings, most notably child development. Its suitability for use in higher education research has been noted (Renn and Arnold, 2003), with some evidence that his model can be used to understand how specific factors influence student learning and development (Wawrzynski, Madden and Jensen, 2012).

Bronfenbrenner notes how learning arises as a by-product of interaction between an individual and their environment:

human development takes place through processes of progressively more complex reciprocal interaction between an active, evolving biopsychological human organism and the persons, objects and symbols in its immediate external environment. To be effective, the interaction must 
occur on a fairly regular basis over extended periods of time.

(Bronfenbrenner, 1999, p.5.)

The model highlights the importance of interaction (as opposed to passive consumption) while noting that such interaction needs to be progressively more complex if the individual is to learn and develop. Time is also significant for, just like an adult looking to lose weight by joining a gym, unless the individual engages in regular participation in an activity over an extended period, any learning or development will be limited.

The role of interaction between an individual and his/her environment in the learning process is a common theme in established theory. Similar ideas underpin student involvement theory (Astin, 1999), experiential learning theory (Kolb and Kolb, 2005) and the concept of situated learning in communities of practice (Lave, 1991; Lave and Wenger, 1991). These perspectives all note the role of inter-action between the individual and their environment supporting a conception of the undergraduate student experience based around the student (and their individual circumstances), the factors that define the student's environment and the process by which they interact with that environment.

\section{The Undergraduate Student and his/her Environment}

This section will explore how the multiple factors that shape the student's environment can be accommodated within a framework for analysis. To do this the paper again draws from Bronfenbrenner's $(1977,1994,1999)$ ecological model. This model places individuals at the centre of a series of structures, known as the macrosystem. The macrosystem represents the overarching characteristics of a culture or sub-culture. Within the broader student experience macrosystem, the student encounters a variety of influences known as microsystems all of which have the capacity to shape the student's experiences. Microsystems are defined as the: 'pattern of activities, social roles, and interpersonal relations experienced by the developing person in a given face-to-face setting ... examples include such settings as family, school, peer group and workplace' (Bronfenbrenner, 1994, p.39).

Microsystems that exist in close proximity to the student have the greatest capacity to influence personal development because proximity contributes to greater interaction between an individual and a microsystem. Such microsystems are said to operate in the mesosystem, the most influential structure in day-to-day life. In contrast, microsystems that that operate at a distance exist in the exosystem and have only an indirect influence, as they are one step removed from day-to-day life. This illustrated in figure 1 below. 


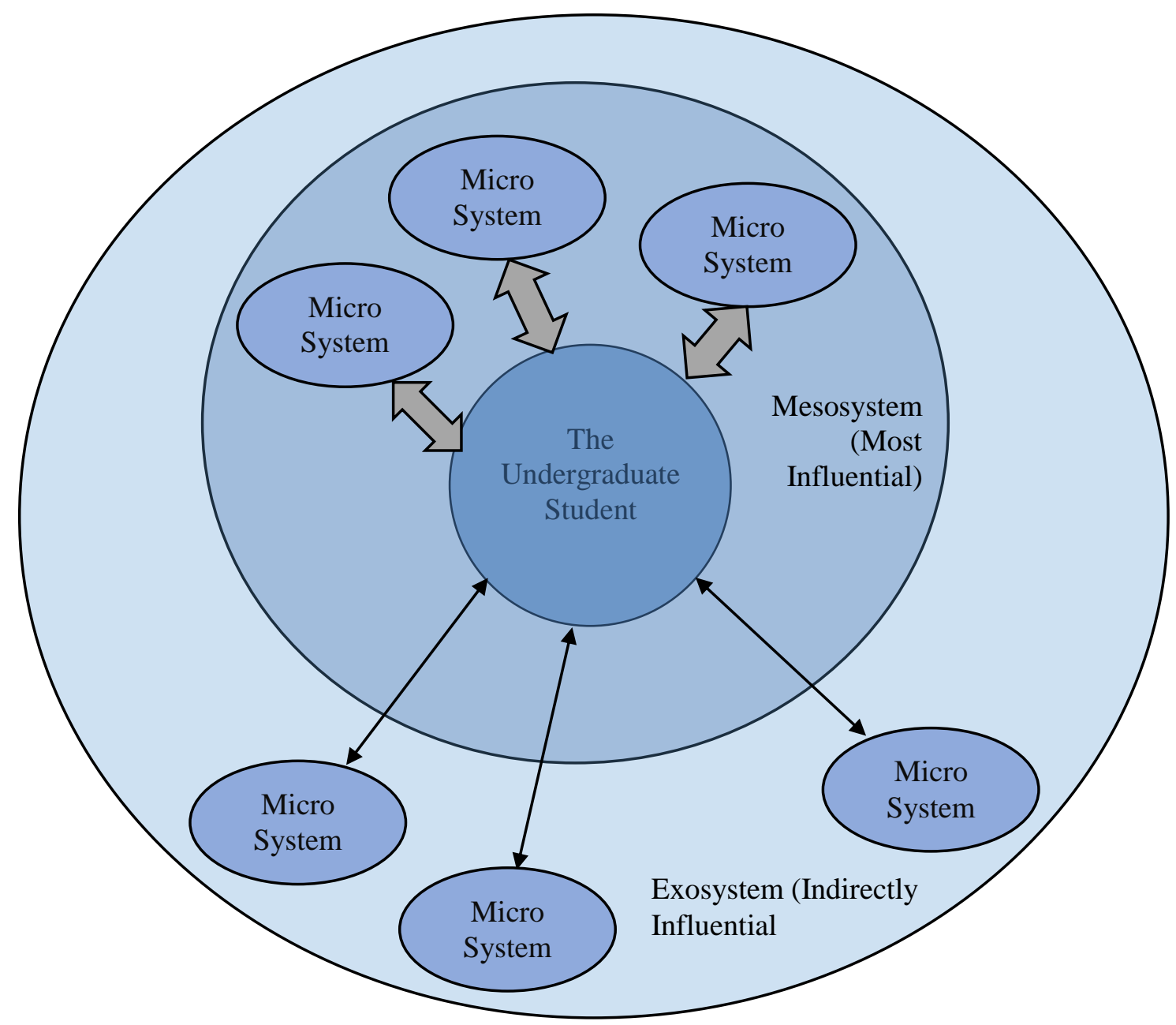

Figure 1 - An Illustration of the Importance of Proximity in Determining the Influence of Microsystems, adapted from Bronfenbrenner (1994) and Renn and Arnold (2003).

Application of Bronfenbrenner's conception of a microsystem allows us to group together the influences on student life into meaningful classifications. Bronfenbrenner's model is also sufficiently flexible to allow us to incorporate wider elements of a student's environment, to include social and cultural dimensions such as peers, friends, family and extracurricular activity (Atkins, 1999; Kuh, 1995). Thus, the approach to answering the first question posed by this paper, what are the key influences that shape the student experience, will be to identify the set of microsystems that operate in closest proximity to the student as it is these microsystems that have the greatest capacity to shape the lifeworld of the undergraduate student.

To do this the next section of the paper will draw from a substantial body of theoretical and empirical evidence to identify those microsystems that define the environment in which the student experience unfolds, drawing from the template of the student journey through undergraduate life (Case, 2008; Temple et al., 2014). The student journey is an appropriate reference point because it offers a coherent and broadly based model of the student's 
progression from the application stage, through the academic experience, wider student life and preparation for life after graduation (Temple et al., 2014), incorporating the stages of entering, fitting in and staying in the higher education community (Case 2008). Using this approach seven key microsystems representing the student journey are identified.

\section{Key Elements of the Undergraduate Student Environment: The Seven Microsystems}

\section{The Pre-University Phase}

The literature suggests that students arrive at university with views and expectations about their student experience, highlighting how the pre-university phase can influence the undergraduate student experience. While university offers opportunities for students to develop and refine their identity in the light of new experiences (Stevenson and Clegg, 2011) there is also evidence that socio-economic factors will already have shaped students' expectations about what is possible and achievable through the composition of students' social networks e.g. family, friends and school or college (Brooks, 2002, 2003, 2004). Furthermore, tacit messages from schools are also an influence on expectations (Donnelly, 2015).

Studies by Hockings, Cooke and Bowl (2007) and Nevill and Rhodes (2004) report on the views of students planning to go to university as to what they think student life will be like. They identify themes of a practical nature to do with finance and debt but also emotional elements such as making friends, settling in and achieving a sense of belonging. While these uncertainties affect all new undergraduates, there are differences in how these issues are perceived with differences in socio-economic background (Thomas, 2002; Wilcox, Winn and Fyvie-Gauld, 2005).

It is also suggested that the characteristics of students entering higher education in the $21^{\text {st }}$ century differ from those of the academic staff who teach them (Coomes, 2004; DeBard, 2004; Taub, 2008), with the greater emphasis placed on rules and complying with rules within schools (and society generally) having an influence on attitudes and behaviours. DeBard (2004) argues that this influence has shaped students' expectations to the extent that it: 'has resulted in a need for and expectation of structure on the part of millennial students' (p.35), with the result that incoming undergraduates might have different attitudes towards the uncertainties, ambiguities and freedoms of student life than the academics who teach them.

Collectively, these studies suggest that the pre-university phase sets the scene for students' adjustment to student life. The background and experiences of an incoming student can contribute to expectations (both of success and failure) and the confidence with which a student approaches their transition into student life.

\section{Transition - Settling into Student Life}

Many of the themes arising in the pre-university phase are also significant during transition. Transition involves a time of considerable change, posing emotional challenges as students struggle to make sense of their new environment and establish their identity as an undergraduate (Beard, Clegg and Smith, 2007). Christie et al., (2008) note how joining university can be: 'an emotional process that can incorporate feelings of alienation and exclusion, as well as of excitement and exhilaration.' (p.567). While Palmer, O'Kane and 
Owens (2009) describe how students inhabit a state of 'in-between-ness' as they move between a sense that they belong at home and a sense that they belong at university.

Where students fail to establish feelings of belonging, the likelihood is that the student will not identify with university life, leading to little or no interaction with it, and significantly increasing the risk of dropout or withdrawal (Tinto, 1975). For this reason, successful social integration into student life can be an important precursor to subsequent academic progression and achievement (Bennett, 2003; Thomas, 2000; Wilcox, Winn and Fyvie-Gauld, 2005). Thus, the evidence suggests that much of the learning that takes place during the first year at university is directed towards coping with change and adapting to a new environment. However, there is evidence that those students following a non-traditional route, such as parttime students, face greater and different challenges in establishing a sense of belonging (Kember, Lee and Li, 2001).

\section{University Peer and Friendship Groups}

The influence of university peer and friendship groups, identified during the transition phase, remains strong for the duration of the undergraduate student experience, contributing both to social learning and emotional well-being (Brooks, 2007; Thomas, 2002; Wilcox, Winn and Fyvie-Gauld, 2005).

For students moving away from home to study at university, the shared experience of living with other students, spending a significant amount of time together, enables relationships to develop that are closer, deeper and more open than those previously experienced (Brooks, 2007). For some, this experience is sufficiently strong for university friends to be perceived to fulfil a similar support role at university that family had at home (Thomas, 2002; Wilcox, Winn and Fyvie-Gauld, 2005).

However, the role of university peers and friends is not confined to social interaction and support. University peers and friends can also influence the academic and personal development of students. For example, peers and friends can be influential in determining whether or not a student completes their programme of study (Bank, Slavings and Biddle, 1990; Tinto, 1975). Meanwhile the capacity of more experienced peers to mentor new students enhances new students' sense of belonging and involvement, through a process of socialization (Allen, McManus and Russell, 1999; Jackling and MacDowell, 2008).

University peers and friends can also influence a student's willingness to engage in wider developmental activities (Brooks and Waters, 2010) and the nature and extent of the learning derived from that participation (Kuh, 1995). These processes and perceptions are significant as they are part of how students develop a sense of identity and belonging, fitting into a wider picture of individual development (Bank, Slavings and Biddle, 1990; Brooks, 2007).

\section{Social Background outside University}

As noted previously, socio-economic factors play a significant part in students' expectations and choice of university. However, once a student arrives at university, they become exposed to a range of new influences outside their existing social background, creating the potential for students to exercise greater choice over how they spend their time and how they conduct their lives.

Despite this, social background remains an important influence (Elkins, Braxton and James, 2000; Coomes and DeBard, 2004); with evidence that parents continue to be a significant 
source of values, particularly in relation to expected levels of academic achievement (Bank, Slavings and Biddle, 1990; Taub, 2008) and, depending on the circumstances this can act to the benefit or detriment of students (Thomas, 2002).

Innovations in technology have made it easier for students and their families to remain connected with each other's day-to-day lives while at university (Coomes, 2004). While there is a risk that this may inhibit students' independence and development, with the consequence that they remain overly reliant on their parents, regular dialogue and communication can enable parents to provide on-going support and encouragement, giving their children greater confidence to cope with challenges and thereby helping them develop into independent, autonomous adults (Taub, 2008).

Along with peers and popular culture, family is also found to be influential in how students develop opinions about employability post-graduation (Byrne and Willis, 2005; Cory, Kerr and Todd, 2007; Rothwell, Herbert and Rothwell, 2008).

\section{The Degree Programme}

Students begin to experience and form impressions about teaching and learning at university from early in their first year, as they begin a process of academic transition (Geiger and Ogilby, 2000; Sander et al., 2000; Wingate, 2007). Academic staff have an important role in facilitating this transition both formally, in how they approach teaching and learning and informally, in how they interact with students (Chickering and Gamson, 1987; Pascarella and Terenzini, 1980; Vermeulen and Schmidt, 2008).

This perspective re-inforces the principle that academics need to concentrate first and foremost on the desired outcomes of student learning (Astin, 1999; Chickering and Gamson, 1987) rather than merely following a proscribed procedure. Innovative teaching and learning methods can be an effective way of encouraging students to engage with their studies (Friedlan, 1995; van Eps et al., 2006; Weil et al., 2001). However, there is also the risk that innovative approaches can be unsettling and unfamiliar for some students and therefore have the capacity to alienate rather than engage (Dean and Jolly, 2012; Sander et al., 2000).

Overall, there is a sense that although the degree programme is the primary reason why a student attends university, there is a risk that its influence can be limited. For the degree to shape the student experience, the student needs to feel engaged with (rather than alienated from) their studies and academic staff are essential to the facilitation of this.

\section{Extra-curricular Activity}

Extra-curricular involvement provides an important vehicle for learning and personal development. Indeed, there is evidence that it can support the taught curriculum by providing an opportunity for students to see in practice some of the issues discussed in class (Atkins, 1999; Kuh, 1995). This underlines the need to conceive of undergraduate learning in broad terms, including aspects of personal development as well as more formal academic learning. Kuh (1995) refers to this as the "other curriculum", discussing the significant developmental role of extra-curricula involvement, and stating that: "Students benefit in many ways from out-of-class experiences, ranging from gains in critical thinking to relational and organizational skills, attributes that are highly correlated with satisfaction and success after college' (p.150). 
Similar findings arise in relation to paid work experience; with evidence that where students have work experience they also tend to adopt a more positive view of learning generally (Blackwell et al., 2001) as well as having greater success in entering the labour market (Blackwell et al., 2001; Gault, Redington and Schlager, 2000).

This has particular resonance for those undergraduates who expect to enter the labour market on graduation. There is evidence that prospective employers seek graduates who can offer a rounded set of capabilities; some of which are over and above those that could reasonably be developed solely by completing a degree programme (Hinchliffe and Jolly, 2011; Tomlinson, 2007). There is also evidence that undergraduates look to their universities to provide leadership in this area, with the result that those institutions that place a high value on such activities can have a significant positive influence on the level and extent of extra-curricular involvement amongst the student body (Jones and Hill, 2003; Kuh, 1995).

\section{Preparing for Life after Graduation}

While graduation may mark the end of the undergraduate student journey, there is evidence that preparing for life after graduation can be an important influence on student life (Temple et al. 2014), whether the next step after graduation involves entry into the labour market or further study. For those students for whom employability is a key priority, particularly in more applied disciplines such as business (Kavanagh and Drennan, 2008; Wilton, 2008), there is a clear preference for their degree programme to be professionally or vocationally "relevant" (Carr, Chua and Perera, 2006; El Ansari and Oskrochi, 2006).

Preparing students for the labour market has been a recurring theme in higher education policy in the last 20 years (Bridgstock, 2009) and in the UK, successive reports by Dearing (NCIHE, 1997) and Leitch (2006) have sought to influence the university curriculum. Students are aware that entry into the graduate labour market is not straightforward and that employers require applicants to be able to demonstrate a range of skills and capabilities (Glover Law and Youngman, 2002; Tomlinson, 2007). However, students may only have moderate levels of awareness as to how their experiences in higher education can be used to demonstrate their suitability to employers and achieve the desired success in the labour market (Atkins, 1999; Glover Law and Youngman, 2002).

This creates a "scary gap" for many undergraduates as they have to develop new skills and abilities and learn how to sell these to employers in time for their entry into the labour market post-graduation. For some, learning and development connected with entry into the labour market post-graduation becomes a significant influence on their undergraduate student experience, as they seek to differentiate themselves from other undergraduates and secure well-paid employment; while others are alienated by the regimentation of this process (Jary and Lebeau, 2009; Tomlinson, 2007).

\section{Taking Stock}

In the previous section, Bronfenbrenner's $(1977,1994,1999)$ ecological model was used as a framework to help de-construct the undergraduate student experience. Using the concept of the student journey as a framework for analysis, seven microsystems were defined by identifying themes in the literature and amalgamating them into microsystem entities. Considerable assurance as to the validity and significance of the seven microsystems is provided by the substantial theoretical and empirical evidence underpinning the studies cited. Thus, it is argued that the undergraduate student experience can be articulated in terms of 
interaction with the seven microsystems identified, as these seven microsystems form the defining features of the student experience macrosystem.

This is summarised in figure 2 below.

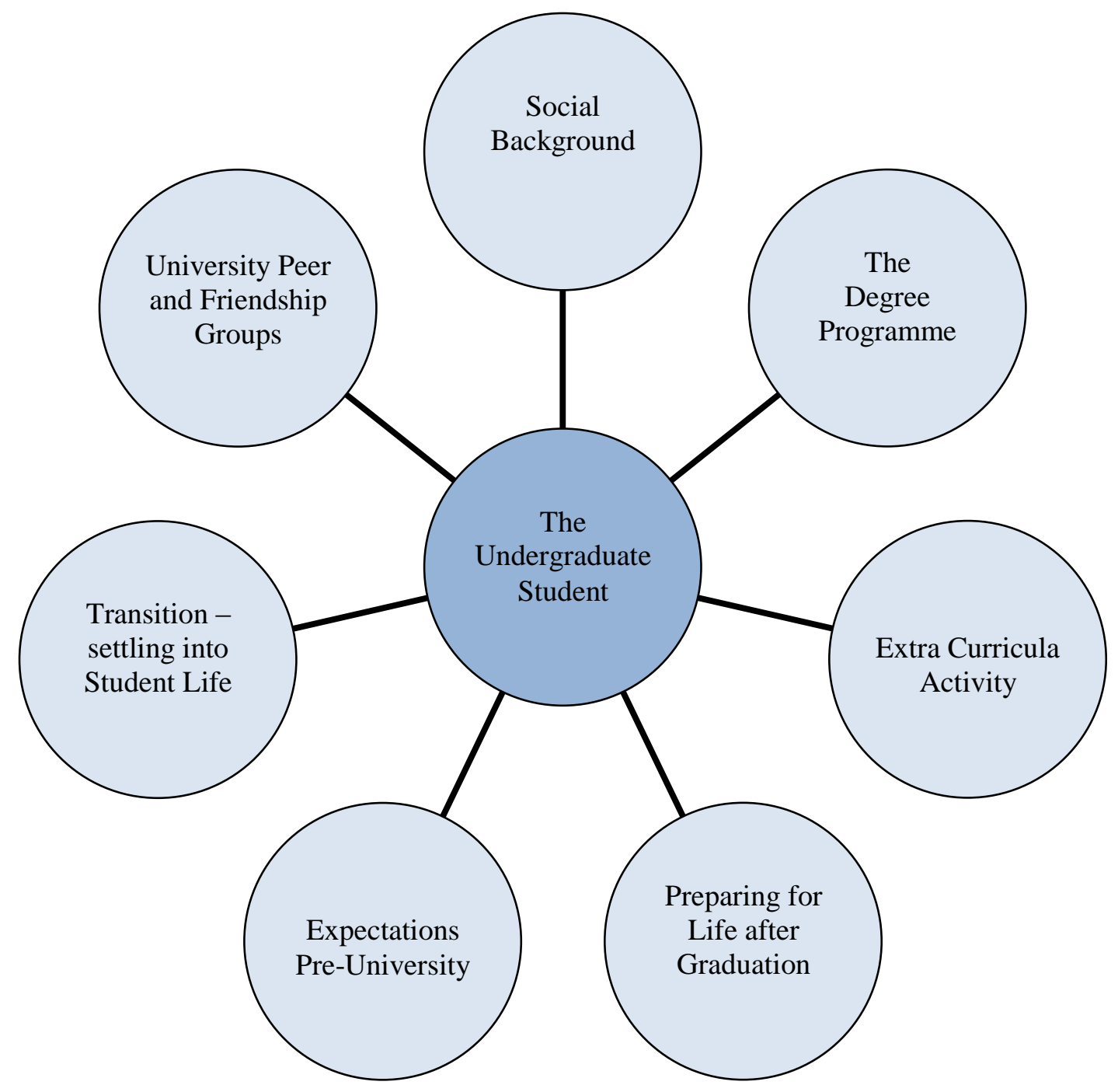

Figure 2 - The Undergraduate Student Experience as Interaction with Influential Microsystems.

However, while figure 2 notes that interaction takes place between the undergraduate student and each microsystem (through the lines that link the individual student with each of the microsystems) it does not identify the extent of that interaction. Indeed, figure 2 suggests (implicitly) that each of the microsystems apply an equal level of influence on each undergraduate. Clearly this is highly unlikely given the diversity of the undergraduate population in matters such as socio-economic background, gender and ethnicity. Thus, the model needs to be developed further to identify how each microsystem might influence an individual student according to his/her individual circumstances. 
As noted earlier, the proposition that the influence of a microsystem will be determined by the extent that the individual interacts with it is consistent with established learning theories (e.g. Astin, 1999, Bronfenbrenner, 1977, 1994, 1999; Kolb and Kolb, 2005; Lave, 1991; Lave and Wenger, 1991). Further, a high level of interaction is consistent with a greater level of influence while a low level of interaction is likely to render the microsystem peripheral. Understanding how an individual student interacts with a microsystem requires explicit consideration of the lifeworld of the undergraduate student, as experienced by them. For this reason, the model can be flexed to accommodate matters such as gender, ethnicity and socioeconomic background, just as Bronfenbrenner used his model to assess environmental factors influencing the impact of parental involvement on child development. This is discussed in the next section.

\section{Interaction between the individual and the microsystems - the importance of engagement and alienation}

This section examines the second question identified in the introduction to this paper: how do the seven microsystems shape the student experience. The paper argues that this is best considered using the established concepts of engagement and alienation. For, if learning is a by-product of the interaction between an individual and their environment, then it is the concepts of student engagement and alienation that explain the strength and depth of that interaction.

Student engagement has received considerable attention in the literature over a number of years. While earlier studies emphasised the role of student involvement and participation, for example Chickering and Gamson (1987) noted that students: "must make what they learn part of themselves" (p.1) and that: "time plus energy equals learning" (p.2), more recent contributions have defined engagement as a process. Thus, Krause and Coates (2008) state that: "student engagement develops from the dynamic interplay between student institutional activities and conditions" (p.495). While Kahu (2013) concludes, it is a: "psycho-social process, influenced by institutional and personal factors, and embedded within a wider social context" (p.768).

While this work has an important role in developing and refining theory, it also has practical implications for higher education practice as successive studies have established an evidence base that students' active participation in purposeful activities is closely linked to their learning and personal development (Trowler, 2010). Indeed, in the USA (National Survey of Student Engagement, 2015), South Africa (Strydom and Mentz, 2010), New Zealand and Australia (UES Consortium, 2015) the measurement of student engagement is being used by some universities as a proxy for determining the quality of the student experience.

In contrast, the concept of student alienation has perhaps received less attention. Studies which have examined the concept suggest that alienation arises from a complex cocktail of factors. For example, Mann (2001) presents an exploration of seven different perspectives on understanding alienation, which include wider societal structures of power, politics and culture. The emergence of students' own set of values at university (Brooks, 2007) can lead to a clearer identification of the "possible self" that they wish to realise after graduation (Stevenson and Clegg, 2011). However, not all students conform to a stereotypical pattern of progression into working life, some wish to immerse themselves fully in the here and now of student life (Stevenson and Clegg, 2011) while others display feelings of anxiety and disaffection about life after graduation, leading to retreatism (Tomlinson, 2007). Certainly, 
feelings of disaffection can have significant consequences with a lack of integration into student life being instrumental in a student withdrawing from university (Tinto, 1975) or resulting in challenging and/or disruptive behaviour (Dean and Jolly, 2012).

Overall, a picture emerges of alienation as a blocking and repelling force which results in the student ceasing to interact with an element of student life, pushing that element to the periphery with the result that it has, at best, a superficial influence on the student experience.

In line with Kahu (2013) who emphasises the importance of context, there is a further aspect of student life that needs to be considered, that of freedom of choice. If one compares the situation of a new undergraduate with that of a new army recruit, there is a sharp contrast. Both are entering a new environment and both would expect to encounter a period of change and development. However, while becoming a student might involve challenges in adjusting to student life (Brooks, 2007; Palmer, O'Kane and Owens, 2009; Wilcox, Winn and FyvieGauld, 2005), the student retains considerable freedom in making this adjustment, unlike a new soldier who has to adapt to the disciplines and rigours of army life, including the potential risks to their personal well-being and safety.

Thus, the influences shaping student behaviour can be characterised as permissive, something that has a significant implication for the student experience. Undergraduates cannot be compelled to engage with student life, indeed efforts to compel could generate feelings of alienation. This underlines the need to empathise with the student's lifeworld as those factors that shape the individual's circumstances such as socio-economic background, gender and ethnicity will also influence the student's willingness to engage and their capacity to be alienated by aspects of their student experience.

Thus, the concepts of engagement and alienation are crucial to an understanding of the student experience as they give meaning to the process of interaction between a student and their environment. They recognise that an individual student has the freedom to feel engaged or alienated and to choose which aspects of their lifeworld to engage with, based on their individual circumstances. They also underline how an engaged student is motivated to use their full energies to interact more actively with their environment, leading to a greater level of learning and development. In contrast, where the student is alienated then the level of interaction is limited with the result that learning is at best ephemeral and superficial.

\section{The Conceptual Framework}

Drawing from Bronfenbrenner's ecological model of human development (1977, 1994, 1999), a model is proposed where the undergraduate student experience is shaped by interaction between the student and their environment and where the influences shaping the environment are classified into seven microsystems that reflect the student journey through undergraduate life. The concepts of engagement and alienation are applied to explain how some microsystems figure prominently in an individual's student experience while others do not.

Thus, the model has relevance on a macro scale for all students, but it can also be applied to the micro circumstances of individual students. For example, students whose individual circumstances contribute to a view of higher education as a staging post to professional and career success (Jary and Lebeau, 2009; Tomlinson, 2007) may be predisposed towards engagement with the degree programme microsystem, but largely to help realise their career goals. Such students choose to engage with those microsystems that enable them to 
demonstrate the portfolio of capabilities required to meet employers' conceptions of "graduateness" (Hinchliffe and Jolly, 2011). In contrast, other students who hold different perspectives may feel alienated by this view of higher education, consistent with Tomlinson's discussion of "retreatism" (2007) and Mann's classifications of alienation (2001).

In these two contrasting cases, there is a common theme that links the groups. It is the individual circumstances and pre-dispositions of the student that determines the extent to which they engage with or feel alienated by their experiences. This is illustrated further in figures 3 and 4 below.
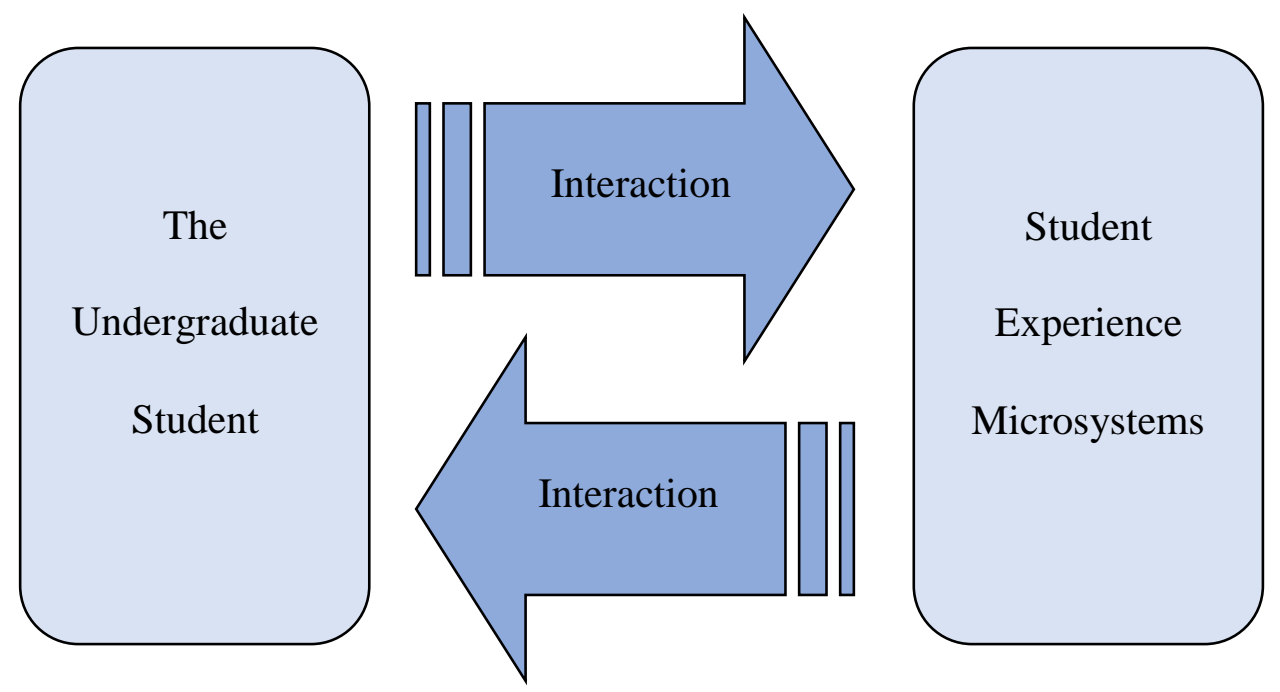

Figure 3 - The Undergraduate Student Experience is Shaped by Interaction with Influential Microsystems.

In figure 3, the student interacts repeatedly with the microsystem because the student has chosen to engage. Engagement acts as an enabling force facilitating greater interaction and bringing the student and microsystem into closer proximity. Learning is facilitated through on-going and progressively more complex interaction (Bronfenbrenner 1977, 1994, 1999). Closer proximity ensures that the microsystem is influential in shaping the student experience. 


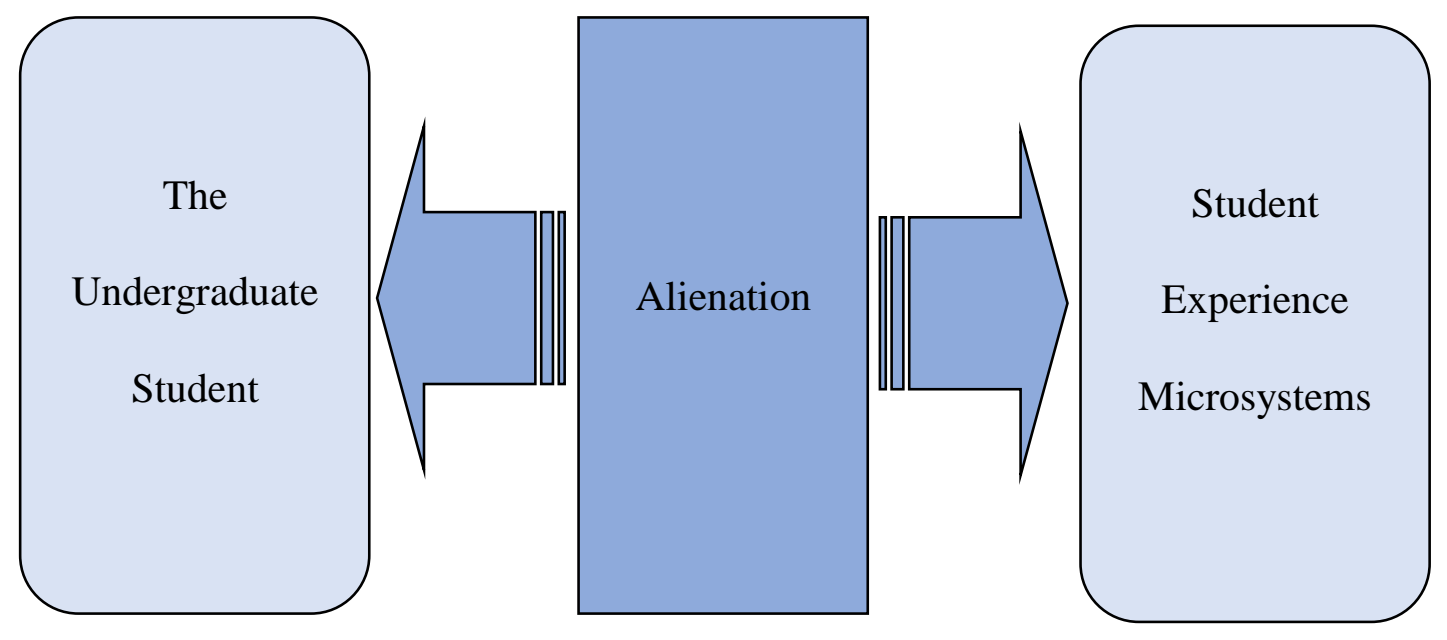

Figure 4 - The Undergraduate Student Experience is Shaped by the Blocking and Repelling Force of Alienation, the Student does not Interaction with the Microsystem(s) with the Result that it is Peripheral to the Student's Life.

In figure 4, the student experiences feelings of alienation and therefore chooses not to interact with the microsystem(s). Alienation acts as a blocking and repelling force with the result that the microsystem(s) become ever more peripheral in the student experience, exerting less and less influence.

Overall, it is the individual's pattern of interaction with the seven microsystems that shapes their student experience. Feelings of engagement or alienation in relation to individual microsystems are re-inforced or contested by the interactions taking place with the other microsystems. In this way, the model maintains its relevance to the individual student as it is the individual mix of experiences and interactions with the seven microsystems reflecting, in part, the individual circumstances of the student that shape his/her student experience. This is a model that can be customised for the individual irrespective of socio-economic background, ethnicity, gender or age for it recognizes that the circumstances of the individual can leave them pre-disposed to a pattern of engagement or alienation. However, exposure to the new influences and experiences presented by undergraduate life can change the predispositions of the individual. This reflects the life-changing potential of higher education and its capacity to contribute to broader desires for independence and autonomy.

\section{Conclusions and Implications for Practice}

The model of the student experience advanced in this paper is less a model of scholarship, but more a model of wider learning and personal development. Indeed, it suggests there is a risk of placing too much emphasis on scholarship at the expense of the encouragement of wider engagement. For, if a university really wishes to engage its students, then the theoretical and empirical evidence suggests that it needs to take account explicitly of the circumstances and motivations of its undergraduates and provide a more broadly-based learning environment; one that is more closely aligned to its intake of students rather than one based on the pretence 
that one size fits all. This acknowledges that scholarship is part of a bigger picture and requires a more integrated multi-dimensional approach where the student experience is considered as a whole.

In line with Douglas et al. (2015) the model provides a mechanism whereby positive and/or negative personal experiences can shape the student experience through their impact on students' feelings of engagement and alienation. For example, the manner and demeanour of academic staff in their interaction with students can engender powerful positive or negative emotions which can leave a lasting impression. This suggests that teaching staff should engage with students to better understand their background and motivations (Mann, 2001) as "frequent student-faculty contact in and out of classes is the most important factor in student motivation and involvement" (Chickering and Gamson, 1987, p.1). Furthermore, encouraging students to engage with each other would enable academics to facilitate a collective endeavour towards learning, something that enriches students both individually and collectively (Chickering and Gamson, 1987; Kahn, 2014).

Recognition and appreciation of the "socio-cultural perspective" (Kahu, 2013, p.763) of student engagement involves taking account of the pre-university perspectives of students (Brooks, 2002, 2003, 2004; Coomes, 2004, Donnelly, 2015; Taub, 2008) and the underlying transition process taking place during the first year (Christie et al., 2008; Palmer, O'Kane and Owens, 2009). Moreover, understanding the influence of peers, friendship groups and family is fundamental to understanding and empathising with the lifeworld of undergraduates (Bank, Slavings and Biddle, 1990; Brooks, 2007; Thomas, 2002; Wilcox, Winn and FyvieGauld, 2005), something that can be particularly important for non-traditional students.

Furthermore, this model also directly addresses one of the fundamental criticisms of traditional learning theory, that it represents the student as: "an anonymous, decontextualized, degendered being" (Malcolm and Zukas, 2001, p.38) by acknowledging the role played by feelings and emotions in the learning process (Krathwohl, Bloom and Masia, 1964; Trigwell, Ellis and Hann, 2012).

This perspective is not based on the model of the student as customer. Instead, it re-affirms that students are members of an academic learning community. Status as members of the academic community grants rights but also places responsibilities upon students to respond to challenges to develop into independent, autonomous adults. In this way, feelings of entitlement both amongst staff and students are tempered by corresponding responsibilities, achieving a sense of balance and equilibrium.

The conception of students as members of a community also recognises that the undergraduate student experience is too broad and diverse to be looked at solely through the lens of the academic programme. To be relevant to the student it needs to engage across a range of elements, especially given the costs of completing an undergraduate degree. For example, undergraduates in the UK have become fee paying rather than funded members of the academic community, a status that raises expectations about the level of return for the investment being made.

\section{Implications for Further Study}

The framework presented in this paper is for undergraduate students. The question arises as to whether it could be adapted to the circumstances of postgraduates. Given the broad 
applicability of the model's theoretical base, this would seem possible as the principal revisions required would be to re-draw the influential microsystems. Postgraduates would be expected to have prior experience of higher education, thereby reducing the influence of the transition process and placing a greater emphasis on life after graduation. However, where the student had moved countries there may be a greater need to accommodate cultural issues.

Similarly, while the model is based around seven key microsystems that influence the student experience, it would be interesting to explore each of these factors in greater depth. In this model the seven microsystems identified are drawn from the data collected and theoretical perspectives advanced in the existing literature. However further study would confirm the validity of the classifications used. Similarly, the processes through which a student engages with or feels alienated from a microsystem and the corresponding way in which that microsystem waxes or wanes in influence is a complex one. The level of understanding of this process could be improved through further research. 


\section{References}

Ainley, P. (2008) The varieties of student experience - an open research question and some ways to answer it, Studies in Higher Education, Volume 33 Number 5, pp 615-624.

Allen, T. D., MacManus, S. E. and Russell, J. E. A. (1999) Newcomer Socialisation and Stress: Relationships as a Source of Support, Journal of Vocational Behavior, Volume 54, pp 453-470.

Astin, A.W. (1999) Student Involvement: A Developmental Theory for Higher Education, Journal of College Student Development, Volume 40 Number 5, pp 518-529.

Atkins, M. J. (1999) Oven-ready and Self-basting: taking stock of employability skills, Teaching in Higher Education, Volume 4 Number 2, pp 267-280.

Bank, B.J., Slavings, R.L. and Biddle, B.J. (1990) Effects of Peer, Faculty and Parental Influences on Students' Persistence, Sociology of Education, Volume 63 Number 3, pp 208225 .

Beard, C., Clegg, S. and Smith, K. (2007) Acknowledging the affective in higher education, British Educational Research Journal, Volume 33 Number 2, pp 235-252.

Bennett, R. (2003) Determinants of Undergraduate Student Drop Out Rates in a University Business Studies Department, Journal of Further and Higher Education, Volume 27 Number 2, pp 123-141.

Blackwell, A., Bowes, L., Harvey, L., Hesketh, A. J. and Knight, P. T. (2001) Transforming Work Experience in Higher Education, British Educational Research Journal, Volume 27 Number 3, pp 269-285.

Bridgstock, R., (2009) The graduate attributes we've overlooked: enhancing graduate employability through career management skills, Higher Education Research and Development, Volume 28, Number 1, pp 31-44.

Bronfenbrenner, U (1977) Toward an Experimental Ecology of Human Development, American Psychologist, Volume 32 Number 7, pp 513-531.

Bronfenbrenner, U (1994) Ecological models of human development, In T. Husten \& T. N. Postlethwaite (Eds), International Encyclopedia of Education, Volume $32^{\text {nd }}$ Edition pp 16431647, New York: Elsevier Science.

Bronfenbrenner, U. (1999) Environments in Developmental Perspective: Theoretical and Operational Models, in Friedman, S.L. and Wachs, T.D., Measuring environment across the life span: Emerging methods and concepts pp 3-28, Washington DC American Psychological Association Press.

Brooks, R. (2002) "Edinburgh, Exeter, East London - or employment?" A review of research on young people's higher education choices, Educational Research, Volume 44 Number 2, pp 217-227. 
Brooks, R. (2003) Young People's Higher Education Choices: The role of family and friends, British Journal of Sociology of Education, Volume 24 Number 3, pp 283-297.

Brooks, R. (2004) "My mum would be as pleased as punch if I actually went, but my dad seems a bit more particular about it": paternal involvement in young people's higher education choices, British Educational Research Journal, Volume 30 Number 4, pp 495-514.

Brooks, R. (2007) Friends, peers and higher education, British Journal of Sociology of Education, Volume 28 Number 6, pp 693-707.

Brooks, R. and Waters, J. (2010) Social networks and educational mobility: the experiences of UK students, Globalisation, Societies and Education, Volume 8 Number 1, pp 143-157.

Byrne, M. and Willis, P. (2005) Irish secondary students' perceptions of the work of an accountant and the accounting profession, Accounting Education, Volume 14 Issue 4, pp 367381.

Carr, S., Chua, F. and Perera, H. (2006) University Accounting Curricula: The Perceptions of an Alumni Group, Accounting Education, Volume 15 Issue 4, pp 359-376.

Case, J.M. (2008) Alienation and engagement: development of an alternative theoretical framework for understanding student learning, Higher Education, Volume 55 issue 3, pp 321-332.

Chickering, A.W. and Gamson, Z.F. (1987) Seven Principles for Good Practice in Undergraduate Education, Insert to The Wingspread Journal, Volume 9 Number 2, pp 1-11.

Christie, H., Tett, L., Cree, V. E., Hounsell, J. and McCune, V. (2008) A real rollercoaster of confidence and emotions: learning to be a university student, Studies in Higher Education, Volume 33 Number 5, pp 567-581.

Coomes M. D. (2004) Understanding the historical and cultural influences that shape generations, New Directions for Student Services, Volume 2004 Issue 106, pp 17-31.

Coomes M. D. and DeBard R., (2004) A Generational Approach to Understanding Students, New Directions for Student Services, Volume 2004 Issue 106, pp 5-16.

Cory, S. N., Kerr, D. and Todd, J. D. (2007) Student Perceptions of the Insurance Profession, Risk Management and Insurance Review, Volume 10 Issue 1, pp 121-136.

DeBard, R., (2004) Millennials coming to college, New Directions for Student Services, Volume 2004 Issue 106, pp 33-45.

Dean, K.L. and Jolly, J.P. (2012) Student Identity, Disengagement, and Learning, Academy of Management Learning and Education, Volume 11 Number 2, pp 228-243.

Donnelly, M. (2015) Progressing to university: hidden messages at two state schools, British Educational Research Journal, Volume 41 Number 1, pp 85-101. 
Douglas, J.A., Douglas, A., McClelland, R.J. and Davies, J. (2015) Understanding student satisfaction and dissatisfaction: an interpretive study in the UK higher education context, Studies in Higher Education, Volume 40 Number 2, pp 329-349.

Elkins, S.A., Braxton, J.M. and James, G.W. (2000) Tinto's Separation Stage and its Influence on First-Semester College Student Persistence, Research in Higher Education, Volume 41 Number 2, pp 251-268.

El Ansari W. and Oskrochi R. (2006) What matters most? Predictors of students satisfaction in public health educational courses, Public Health, Volume 120 Issue 5, pp 462-473.

Friedlan, J. M. (1995) The Effects of Different Teaching Approaches on Students' Perceptions of the Skills Needed for Success in Accounting Courses and by Practicing Accountants, Issues in Accounting Education, Volume 10 Issue 1, pp 47-63.

Gault, J., Redington, J. and Schlager, T. (2000) Undergraduate Business Internships and Career Success: Are They Related, Journal of Marketing Education, Volume 22 Number 1, pp 45-53.

Geiger, M. A. and Ogilby, S. M. (2000) The first course in accounting: students' perceptions and their effect on the decision to major in accounting, Journal of Accounting Education, Volume 18 Issue 2, pp 63-78.

Glover, D., Law, S. and Youngman, A (2002) Graduateness and Employability: student perceptions of the personal outcomes of university education, Research in Post-Compulsory Education, Volume 7 Number 3, pp 293-306.

Hinchliffe, G.W. and Jolly, A. (2011) Graduate identity and employability, British Educational Research Journal, Volume 37 Number 4, pp. 563-584.

Hockings, C., Cooke, S. and Bowl, M. (2007) "Academic Engagement" within a widening participation context - a 3D analysis, Teaching in Higher Education, Volume 12 Numbers 56, pp 721-733.

Jackling, B. and McDowall, T. (2008) Peer Mentoring in an Accounting Setting: A Case Study of Mentor Skill Development, Accounting Education, Volume 17 Number 4, pp 447462.

Jary, D. and Lebeau, Y. (2009) The Student Experience and Subject Engagement in UK Sociology: a Proposed Typology, British Journal of Sociology of Education, Volume 30 Number 6, pp 697-712.

Jones, S.R. and Hill, K.E. (2003) Understanding Patterns of Commitment: Student Motivation for Community Service Involvement, The Journal of Higher Education, Volume 74 Number 5, pp 516-539.

Kahu, E.R. (2013) Framing student engagement in higher education, Studies in Higher Education, Volume 38 Number 5, pp 758-773. 
Kahn, P.E. (2014) Theorising student engagement in higher education, British Educational Research Journal, Volume 40 Number 6, pp 1005-1018.

Kavanagh, M. H. and Drennan, L. (2008) What skills and attributes does an accounting graduate need? Evidence from student perceptions and employer expectations, Accounting and Finance, Number 48, pp 279-300.

Kember, D., Lee, K. and Li, N. (2001) Cultivating a sense of belonging in part-time students, International Journal of Lifelong Education, Volume 20 Number 4, pp 326-341.

Kolb, A.Y. and Kolb, D.A. (2005) Learning Styles and Learning Spaces: Enhancing Experiential Learning in Higher Education, Academy of Management Learning and Education, Volume 4 Number 2, pp 193-212.

Krathwohl, D.R., Bloom, B.S. and Masia, B.B. (1964) Taxonomy Educational Objectives: The Classification of Educational Goals: Handbook II: Affective Domain. New York. David McKay Company Inc.

Krause, K-L. and Coates, H. (2008) Students' engagement in first year university, Assessment and Evaluation in Higher Education, Volume 33 Number 5, pp 493-505.

Kuh, G. D. (1995) The Other Curriculum: Out-of-Class Experiences Associated with Student Learning and Personal Development, Journal of Higher Education, Volume 66 Number 2, pp 123-155.

Lave, J. (1991) Situating Learning in Communities of Practice, Perspectives on Socially Shared Cognition, Volume 2, pp 63-82.

Lave, J. and Wenger, E. (1991) Situated Learning: Legitimate peripheral participation, Cambridge, England, Cambridge University Press.

Leitch S (2006) "Prosperity for all in the global economy - world class skills" Final Report HMSO, Norwich.

Malcolm, J. and Zukas, M. (2001) Bridging Pedagogic Gaps: Conceptual discontinuities in higher education, Teaching in Higher Education, Volume 6 Number 1, pp 33-42.

Mann, S. J. (2001) Alternative Perspectives on the Student Experience: alienation and engagement, Studies in Higher Education, Volume 26 Number 1, pp 7-19.

Marton, F. and Säljö, R. (1976) On Qualitative Differences in Learning: Outcome and Process, British Journal of Educational Psychology, Volume 46 Issue 1, pp 4-11.

National Survey of Student Engagement (2015). Engagement Insights: Survey Findings on the Quality of Undergraduate Education - Annual Results 2015, Bloomington, Indiana, USA.

Nevill, A. and Rhodes, C. (2004) Academic and social integration in higher education: a survey of satisfaction and dissatisfaction within a first-year education studies cohort at a new university, Journal of Further and Higher Education, Volume 28 Number 2, pp 179-193. 
NCIHE (1997) Higher Education in the Learning Society (Report of the National Committee of Inquiry into Higher Education: 'The Dearing Report') HMSO, London.

Palmer, M., O'Kane, P. and Owens, M. (2009) Betwixt spaces: student accounts of turning point experiences in the first-year transition, Studies in Higher Education, Volume 34 Number 1, pp 37-54.

Pascarella, E.T. and Terenzini, P.T. (1980) Predicting Freshman Persistence and Voluntary Dropout Decisions from a Theoretical Model, The Journal of Higher Education, Volume 51 Number 1, pp 60-75.

Radloff, A., (Ed.). (2011). Student engagement in New Zealand universities, Australian Council for Educational Research, Camberwell, Australia.

Renn, K.A. and Arnold, K.D. (2003) Reconceptualizing Research on Student Peer Culture, The Journal of Higher Education, Volume 74 Number 3, pp 261-291.

Rothwell, A., Herbert, I. and Rothwell, F. (2008) Self-perceived employability: Construction and initial validation of a scale for university students, Journal of Vocational Behavior, Volume 73, Issue 1, pp 1-12.

Stevenson, J. and Clegg, S. (2011) Possible selves: students orientating themselves towards the future through extracurricular activity, British Educational Research Journal, Volume 37 Number 2, pp 231-246.

Sander, P., Stevenson, K., King, M. and Coates, D. (2000) University Students' Expectations of Teaching, Studies in Higher Education, Volume 25 Number 3, pp 309-323.

Strydom, J.F. and Mentz, M. (2010) South African Survey of Student Engagement, South African Council on Higher Education (CHE), Pretoria, South Africa.

Taub, D. J. (2008) Exploring the Impact of Parental Involvement on Student Development, New Directions for Student Services, Volume 2008 Issue 122, pp 15-28.

Temple, P., Callender, C., Grove, L. and Kersh, N. (2014) Managing the student experience in a shifting higher education landscape, The Higher Education Academy, York, UK.

Thomas, L. (2002) Student retention in higher education: the role of institutional habitus, Journal of Education Policy, Volume 17 Number 4, pp 423-442.

Thomas, S.L. (2000) Ties That Bind: A Social Network Approach to Understanding Student Integration and Persistence, The Journal of Higher Education, Volume 71 Number 5, pp 591615.

Tinto, V. (1975) Dropout from Higher Education: A Theoretical Synthesis of Recent Research, Review of Educational Research, Volume 5 Number 1, pp 89-125.

Tomlinson, M. (2007) Graduate employability and student attitudes and orientations to the labour market, Journal of Education and Work, Volume 20 Number 4, pp 285-304. 
Trigwell, K., Ellis, R.A. and Han, F. (2012) Relations between students' approaches to learning, experienced emotions and outcomes of learning, Studies in Higher Education, Volume 37 Number 7, pp 811-824.

Trowler, V. (2010) Student Engagement Literature Review, The Higher Education Academy, York, UK.

UES Consortium (2015) 2014 University Experience Survey National Report, retrieved 16 May 2016 from: https://www.qilt.edu.au/docs/default-source/ues-national-report/2014university-experience-survey-national-report/ues14_report_final_access2a.pdf?sfvrsn=4

Universities UK (2016) Fulfilling our potential: teaching excellence, social mobility and student choice - Universities UK response, retrieved 16 May 2016 from:

http://www.universitiesuk.ac.uk/highereducation/Pages/ResponseHigherEducationGreenPape r.aspx\#.VznLK-72bIU

van Eps, M.A., Cooke, M., Creedy, D.K. and Walker, R. (2006) Student evaluations of a year-long mentorship program: A quality improvement initiative, Nurse Education Today, Volume 26 Issue 6, pp 519-524.

Vermeulen, L. and Schmidt, H.G. (2008) Learning environment, learning process, academic outcomes and career success of university graduates, Studies in Higher Education, Volume 33 Number 4, pp 431-451.

Wawrzynski, M.R., Madden, K. and Jensen, C. (2012) The Influence of the College Environment on Honors Students' Outcomes, Journal of College Student Development, Volume 53 Number 6, pp 840-845.

Weil, S., Oyelere, P., Yeoh, J. and Firer, C. (2001) A study of students' perceptions of the usefulness of case studies for the development of finance and accounting-related skills and knowledge, Accounting Education, Volume 10 Issue 2, pp 123-146.

Wilcox, P., Winn, S. and Fyvie-Gauld, M. (2005) "It was nothing to do with the university, it was just the people": the role of social support in the first-year experience of higher education, Studies in Higher Education, Volume 30 Number 6, pp 707-722.

Wilton, N. (2008) Business graduates and management jobs: an employability match made in heaven? Journal of Education and Work, Volume 21 Number 2, pp 143-158.

Wingate, U. (2007) A Framework for Transition: Supporting "Learning to Learn" in Higher Education, Higher Education Quarterly, Volume 61 Number 3, pp 391-405. 